J. Dhaka National Med. Coll. Hos. 2012; 18 (01): 58-62

Review Article

\title{
Mushroom is an Ideal Food Supplement
}

\author{
A.J. Kakon ${ }^{1}$, Md. Bazlul Karim Choudhury ${ }^{2}$, Shusmita Saha ${ }^{3}$ \\ ${ }^{1}$ Mushroom Development officer, National Mushroom Development and Extension Centre, Sobhanbag, Savar, Dhaka; ${ }^{2}$ OSD, \\ Directorate General, Health Service, Mohakhali, Dhaka, \\ ${ }^{3}$ Associate Professor (c.c.) of Pharmacology, Dhaka National Medical College
}

\begin{abstract}
Mushroom, a nutrient-dense versatile food can share some of the benefits of fruits and vegetable and complement almost any everyday meal. Mushroom cultivation also requires low technology, low investment and can be grown in very little space. Due to culinary, nutritional and health benefits, the mushroom market is expected to grow as "a food, a tonic and a medicine". In the study food value of mushroom was found comparatively higher than that of other vegetables, fruits, meat and fish. This discussion suggests that the potentiality of mushroom cultivation could be a possible offer to alternate food and develop the life style of the people.
\end{abstract}

Key words: Agrowastes, Fungi, Lignocelluloses, Nutrient, Beta-glucans, Chitosans.

\section{Introduction:}

Mushrooms represent one of the Worlds greatest untapped resources of nutritious food. Cultivation of saprophytic edible mushrooms may be the only currently economical biotechnology for lignocelluloses organic waste recycling that combines the production of protein rich food with the reduction of environmental pollution ${ }^{1}$. Mushrooms are rich in protein, minerals, vitamins, fibers and they contain an abundance of essential amino acids ${ }^{2,5}$. Therefore, mushrooms can be a good supplement to cereals ${ }^{3}$.

Mushroom is being widely used as food and food supplements from ancient times. They are increasingly being recognized as one of the important food items for their significant roles in human health, nutrition and diseases ${ }^{4}$. Mushrooms are recognized as the alternative source of good quality protein and are capable of producing the highest quantity of protein per unit area and time from the worthless agrowastes ${ }^{5}$. Mushrooms can substantiate the sufferings from malnutrition to some extent, because they produce large quantities in a short time and provide more protein per unit area than other crops ${ }^{6}$. They are low in calories, carbohydrates, calcium and sodium. They contain high proportion of unsaturated fat but virtually no harmful lipid or cholesterol. It contains a large amount of vitamins such as Thiamine $1.4-2.2 \mathrm{mg} \mathrm{( \% )}$, Riboflavin 6.7-9.0 mg (\%), Niacin 60.6-73.3 mg (\%), Biotin, Ascorbic acid 92-144 mg (\%), Pantothenic acid 21.1-33.3 mg (\%) and Folic acid 1.2-1.4 mg/100g in dry weight basis ${ }^{7}$. The minerals that found in mushroom are calcium, Iron, Manganese, Magnesium, Zinc, Selenium etc ${ }^{8}$. Mushroom has 1000 of variety to enrich the food basket of human health. It is an alternative rich source of meat, fish, vegetables, fruits etc. Mushroom's nutritional value proves to have many health benefits.
Discussion:

Mushroom is the source of extra ordinary power and virility and is used in the preparation of many essential dishes ${ }^{9}$. Mushroom is a high value crop for domestic and export market. Ogundana and Fagade $(1981)^{10}$ indicated that mushroom is about $16.5 \%$ dry matter out of which $7.4 \%$ is crude fiber, $14.6 \%$ is crude protein and $4.48 \%$ is fat and oil. Protein contents vary 4 to $9 \%$ in Auricularia spp. and 24 to $44 \%$ in Agaricus spp. The protein value of mushrooms is twice as that of asparagus and potatoes, four times as that of tomatoes and carrots, and six times as that of oranges. Their energy value also varies according to species, which is about equal to that of an apple. Mushrooms are a lowcalorie food usually eaten raw or cooked to provide garnish to a meal.

\section{Mushrooms as a source of food}

Thousands of years ago, fructifications of higher fungi have been used as a source of food ${ }^{11}$ due to their chemical composition which is attractive from the nutrition point of view. During the early days of civilization, mushrooms were consumed mainly for their palatability and unique flavors ${ }^{12}$. Present use of mushrooms is totally different from traditional because, lot of research has been done on the chemical composition of mushrooms, which revealed that mushrooms can be used as a diet to combat diseases. The early history regarding the use of mushrooms in different countries has been reviewed by number of workers $^{13,14,15}$.

Lintzel $(1941,1943)^{16}$ recommended that 100 to $200 \mathrm{~g}$ of mushrooms (dry weight) is required to maintain an optimal nutritional balance in a man weighing $70 \mathrm{~kg}$. Bano (1976) ${ }^{17}$ suggested that food value of mushrooms lies between meat and vegetables. Crisan and Sands $(1978)^{18}$ observed that mushrooms generally contain 
J. Dhaka National Med. Coll. Hos. 2012; 18 (01): 58-62 $90 \%$ water and $10 \%$ dry matter. More so, the protein content varies between 27 and 48\%. Carbohydrates are less than $60 \%$ and lipids are between 2 to $8 \%$. Gruen and Wong (1982) ${ }^{19}$ indicated that edible mushrooms were highly nutritional and compared favourably with meat, egg and milk. Of several thousand mushroom species known worldwide, only around 2000 are considered edible, of which about 20 are cultivated commercially with only 4 to 5 under industrial production $^{20}$.

\section{Carbohydrates:}

Florezak et al. (2004) ${ }^{21}$ reported that Coprinus atramentarius contain $24 \%$ of carbohydrate on dry weight basis. The mannitol, also called as mushroom sugar constitutes about $80 \%$ of the total free sugars, hence it is dominant ${ }^{22}$. Mc-Connell and Esselen $(1947)^{23}$ reported that a fresh mushroom contains $0.9 \%$ mannitol, $0.28 \%$ reducing sugar, $0.59 \%$ glycogen and $0.91 \%$ hemicellose. Carbohydrates of Agaricus bisporus were reported by Crisan and Sands (1978a $)^{24}$, raffinose, sucrose, glucose, fructose and xylose are dominant in $\mathrm{it}^{40}$. Water soluble polysaccharides of mushrooms are antitumor ${ }^{25}$.

\section{Proteins:}

Mushrooms are good source of high quality protein. It contains $20-35 \%$ protein (dry wt. basis) which is higher than vegetables and fruits and is of superior quality. It is rich in lysine and tryptophan, the two essential amino acids that are in deficient in cereals. It is also called white vegetables or "boneless vegetarian meat". Protein is an important constituent of dry matter of mushrooms. Protein content of mushrooms depend on the composition of the substratum, size of pileus, harvest time and species of mushrooms ${ }^{3,26}$. Haddad and Hayes $(1978)^{27}$ indicated that protein in $A$. bisporus mycelium ranged from 32 to $42 \%$ on the dry weight basis. Samajipati $(1978)^{28}$ found $30.16,28.16$, 34.7 and $29.16 \%$ protein in dried mycelium of $A$. campestris, A. arvensis, M. esculenta and M. deliciosa respectively. In terms of the amount of crude protein, mushrooms rank below animal meats but well above most other foods including milk ${ }^{29}$. Verma et al. $(1987)^{30}$ reported that mushrooms are very useful for vegetarian because they contain some essential amino acids which are found in animal proteins. Rai and Saxena $(1989 a)^{31}$ observed decrease in the protein content of mushroom on storage. Mushrooms in general have higher protein content than most other vegetables and most of the wild plants ${ }^{32}$. Mushrooms contain all the essential amino acids required by an adult $^{33}$.
Fats:

Mushrooms are low caloric food with very little fat (4$6 \%$ and without cholesterol. Hugaes (1962) observed that mushrooms are rich in linolenic acid which is an essential fatty acid. Total fat content in $A$. bisporus was reported to be 1.66 to $2.2 / 100 \mathrm{~g}$ on dry weight basis ${ }^{35}$. Yilmaz et al. $(2006)^{36}$ and Pedneault et al. $(2006)^{37}$ reported that fat fraction in mushrooms is mainly composed of unsaturated fatty acids.

\section{Vitamins:}

Mushrooms are one of the best sources of vitamins especially Vitamin $B^{3,38}$. Esselen and Fellers $(1946)^{39}$, Litchfield (1964) ${ }^{40}$ and Manning (1985) ${ }^{41}$ gave a comprehensive data of vitamin content of mushrooms and some vegetables. Mushrooms also contain vitamin $\mathrm{C}$ in small amounts ${ }^{11,42}$ and which are poor in vitamins $\mathrm{A}, \mathrm{D}$, and $\mathrm{E}^{43}$.

Table 1: Nutritional Values of Mushroom

\begin{tabular}{|c|c|c|c|c|c|c|c|c|}
\hline \multirow{2}{*}{ Species } & \multirow{2}{*}{$\begin{array}{l}\text { Initial } \\
\text { Moisture }\end{array}$} & \multirow{2}{*}{\begin{tabular}{|l} 
Crude \\
protein \\
Nx4.38
\end{tabular}} & \multirow{2}{*}{ Fat } & \multicolumn{2}{|c|}{\begin{tabular}{|l|} 
Carbohydra \\
te Fiber
\end{tabular}} & \multirow{2}{*}{ Ash } & \multirow{2}{*}{ Energy } & \multirow{2}{*}{$\begin{array}{l}\text { Value } \\
\text { (K.cal) }\end{array}$} \\
\hline & & & & Total & $\begin{array}{l}\mathbf{N}- \\
\text { free }\end{array}$ & & & \\
\hline $\begin{array}{l}\text { Agaricus bisporus } \\
\text { (fresh) }\end{array}$ & 89.5 & 26.3 & 1.8 & 59.96 & 49.5 & 10.4 & 12.0 & 328 \\
\hline $\begin{array}{l}\text { Volvariella } \\
\text { volvacea (fresh) }\end{array}$ & 88.0 & 29.5 & 5.7 & 60.0 & 49.6 & 10.4 & 4.8 & 374 \\
\hline $\begin{array}{l}\text { Il'olvariella } \\
\text { diplosia (fresh) } \\
\end{array}$ & 90.4 & 28.5 & 2.6 & 57.4 & 40.0 & 17.4 & 11.5 & 304 \\
\hline $\begin{array}{l}\text { Lentinula Modes } \\
\text { (fresh) }\end{array}$ & 90.0 & 17.5 & 8.0 & 67.5 & 59.5 & 8.0 & 7.0 & 387 \\
\hline $\begin{array}{l}\text { Pleurotus ostreatus } \\
\text { (fresh) }\end{array}$ & 73.7 & 10.5 & 1.6 & 81.8 & 74.3 & 7.5 & 6.1 & 367 \\
\hline $\begin{array}{l}\text { Auricularia } \\
\text { polytricha (fresh) }\end{array}$ & 87.1 & 7.7 & 0.8 & 87.6 & 73.6 & 14.0 & 3.9 & 347 \\
\hline $\begin{array}{l}\text { Flaninnilbia } \\
\text { velutipes (fresh) }\end{array}$ & 89.2 & 17.6 & 1.9 & 73.1 & 69.4 & 3.7 & 7.4 & 378 \\
\hline $\begin{array}{l}\text { Pholiota naineko } \\
\text { (fresh) }\end{array}$ & 95.2 & 20.8 & 4.2 & 66.7 & 60.4 & 6.3 & 8.3 & 372 \\
\hline $\begin{array}{l}\text { Trcinclla } \\
\text { fuciforinis (dried) }\end{array}$ & 19.7 & 4.6 & 0.2 & 94.8 & 93.4 & 1.4 & 0.4 & 412 \\
\hline
\end{tabular}

$(1978)^{30}$

\section{Mineral constituents:}

The fruiting bodies of mushrooms are characterized by a high level of well assimilated mineral elements. Major mineral constituents in mushrooms are $\mathrm{K}, \mathrm{P}, \mathrm{Na}$, $\mathrm{Ca}, \mathrm{Mg}$ and trace elements like $\mathrm{Cu}, \mathrm{Zn}, \mathrm{Fe}, \mathrm{Mo}, \mathrm{Cd}$ as minor constituents ${ }^{44}$. K, P, Na and $\mathrm{Mg}$ constitute about 56 to $70 \%$ of the total ash content of the mushrooms ${ }^{38}$ while potassium alone forms $45 \%$ of the total ash. Mushrooms have been found to accumulate heavy metals like cadmium, lead, arsenic, copper, nickel, silver, chromium and mercury ${ }^{45,46,47}$. The mineral proportions vary according to the species, age and the diameter of the fruiting body. It also depends upon the type of the substratum ${ }^{48}$. The mineral content of wild 
J. Dhaka National Med. Coll. Hos. 2012; 18 (01): 58-62 edible mushrooms has been found higher than cultivated ones ${ }^{11,26,49}$.

Table 2: Essential Amino Acid in 100 gm Dry

\section{Mushroom}

\begin{tabular}{|l|c|c|c|c|c|c|}
\hline $\begin{array}{l}\text { Ess. Amino } \\
\text { Acid }\end{array}$ & $\begin{array}{l}\text { Agaricus } \\
\text { bisporus }\end{array}$ & $\begin{array}{l}\text { Agaricus } \\
\text { edodes }\end{array}$ & $\begin{array}{l}\text { Pleurotus } \\
\text { florida }\end{array}$ & $\begin{array}{l}\text { Pleurotus } \\
\text { ostreatus }\end{array}$ & $\begin{array}{l}\text { Pleurotus } \\
\text { sajorcaju }\end{array}$ & $\begin{array}{c}\text { Volvereilla } \\
\text { volvacea }\end{array}$ \\
\hline Leucine & 7.5 & 7.9 & 7.5 & 6.8 & 7.0 & 4.5 \\
\hline Isoleucine & 4.5 & 4.9 & 5.2 & 4.2 & 4.4 & 3.4 \\
\hline Valine & 2.5 & 3.7 & 6.9 & 5.1 & 5.3 & 5.4 \\
\hline Tryptophan & 2.0 & - & 1.1 & 1.3 & 1.2 & 1.5 \\
\hline Lysine & 9.1 & 3.9 & 9.9 & 4.5 & 5.7 & 7.1 \\
\hline Threonine & 5.5 & 5.9 & 6.1 & 4.6 & 5.0 & 3.5 \\
\hline Phenylalanine & 4.2 & 5.9 & 3.5 & 3.7 & 5.0 & 2.6 \\
\hline Methionine & 0.9 & 1.9 & 3.0 & 1.5 & 1.8 & 1.1 \\
\hline $\begin{array}{l}\text { Total } \\
\text { essential }\end{array}$ & 38.9 & 36.0 & 46.0 & 33.4 & 37.6 & 32.9 \\
\hline
\end{tabular}

\section{Source: Crisan \& Sands $(1978)^{30}$}

\section{Selenium:}

Mushrooms contain more selenium and all edible mushrooms are good sources of selenuim. Selenuim may also be an anti-cancer substance since it has been proven to reduce the risk of prostate cancer.

\section{Potassium:}

An extremely important mineral that regulates blood pressure and keeps cells functioning properly. Mushrooms are a good source of potassium.

Table 3: Major vitamins and minerals (on dry basis)

\begin{tabular}{|l||l|l||}
\hline $\begin{array}{l}\text { Major } \\
\text { vitamin \& } \\
\text { minerals }\end{array}$ & $\begin{array}{l}\text { Daily } \\
\text { requirement }\end{array}$ & $\begin{array}{l}\text { Mushroom } \\
\text { content }\end{array}$ \\
\hline $\begin{array}{l}\text { Thiamine (B- } \\
\text { ) }\end{array}$ & $1.4 \mathrm{mg}$ & $4.8-8.9 \mathrm{mg}$ \\
\hline $\begin{array}{l}\text { Riboflavin } \\
\text { (B-2) }\end{array}$ & $1.5 \mathrm{mg}$ & $3.7-4.7 \mathrm{mg}$ \\
\hline Niacin & $18.2 \mathrm{mg}$ & $42-108 \mathrm{mg}$ \\
\hline Phosphorus & $450 \mathrm{mg}$ & $708-1348 \mathrm{mg}$ \\
\hline Iron & $9 \mathrm{mg}$ & $15-17 \mathrm{mg}$ \\
\hline
\end{tabular}

\begin{tabular}{|l||l|l|}
\hline Calcium & $450 \mathrm{mg}$ & $33-199 \mathrm{mg}$ \\
\hline Copper & $2 \mathrm{mg}$ & $12-22 \mathrm{mg}$ \\
& & \\
\hline \multicolumn{2}{|c|}{ Source: Crisan \& Sands $(1978)^{30}$}
\end{tabular}

Fiber:

Mushroom contain good quality fibre. It helps in lowering the cholesterol. Aletor $(1995)^{26}$, Sanme et al. $(2003)^{50}$ and Manzi et al. $(2004)^{51}$ worked on the fiber content of different mushrooms. Fresh mushrooms contain both soluble and insoluble fiber. The soluble fiber is mainly beta-glucans and chitosans, which are components of the cell walls. Soluble fiber has been shown to help prevent and manage cardiovascular disease by lowering total and LDL cholesterol levels. It also helps regulate blood sugar levels. So, mushrooms are good for health because it contains zero Fat, low Calories, low Carbohydrates, low Sodium and no Cholesterol.

\section{Conclusion:}

Considering the above discussion it is mentionable that mushroom is nutrient dense, versatile food. It is a treasure for nutrition and can substantiate the sufferings from malnutrition to some extent. It contains more protein, in comparison to other animal and plant food, low carbohydrate, and that too is not in the form of starch rather than in the form of glycogen, zero fat and adequate vitamins \& minerals which is higher than vegetables and fruits and is of superior quality. They are good source of high quality fibers \& low caloric food. So, mushroom is an alternative rich source of meat, fish, vegetables, fruits etc. There is a great scope to use of mushroom as an alternative food and ensure food security for the people. Thus, mushroom is an ideal food supplement, especially in our densely populated country.

\section{References:}

1. Obodai M, Cleland-Okine J, Vowotor KA (2003). Comparative study on the growth and yield of Pleurotus ostreatus mushroom on different lignocellulosic by-products. J. Ind. Microbiol. Biotechnol. 30: 146-149.

2. Sadler M (2003). Nutritional properties of edible fungi. Br. Nutr. Found. Nutr. Bull. 28: 305-308.

3. Chang ST, Buswell JA (1996). Mushroom Nutriceuticals. World J. Microbiol. Biotechnol. 12: 473-476.

4. Chang R (1996). Functional properties of mushrooms. Nutrition Reviews. 54: 91-93. 
J. Dhaka National Med. Coll. Hos. 2012; 18 (01): 58-62

5. Chadha KL \& Sharma SR (1995). Mushroom research in India-History, Infrastructure and Achievements. In KL Chadha (Eds.). Advances in Horticulture. New Delhi: MPH ( Malhotra Publishing House): pp. 1-8.

6. Gupta RS (1986). Mushroom cultivation. Indian Hort. 31(1): 1.

7. Hossain MS, Alam N, Amin SMR, Basunia MA \& Rahman A (2007). Essential Fatty Acid Contents of Pleurotus ostreatus, Ganoderma lucidum and Agaricus bisporus. Bangladesh J. Mushroom. 1(1): 1-7.

8. Alam N, Khan A, Hossain, MS, Amin, SMR \& Khan LA (2007). Nutritional Analysis of dietary Mushroom- Pleurotus florida Eger and Pleurotus sajur-caju (Fr) Singer. Bangladesh J. Mushroom. 1(2): 1-7.

9. Khan SM, Kausar AG \& Ali MA (1981). Yield performance of different stains of Oyster mushroom (Pleurotus spp.) on paddy straw in Pakistan. Mushroom Sci. 11(1): 675-687.

10. Ogundana SK, Fagade O (1981). The nutritive value of some Nigerian edible mushrooms. In: Mushroom Science XI, Proceedings of the Eleventh International Scientific Congress on the Cultivation of Edible Fungi, Australia. pp. 123-131.

11. Mattila P, Konko K, Eurola M, Pihlava JM, Astola J, Vahteristo L, Hietaniemi V, Kumpulainen J, Valtonen M, Piironen V (2001). Contents of vitamins, mineral elements, and some phenolic compounds in cultivated mushrooms. J. Agric. Food Chem. 49(5): 2343-2348.

12. Rai RD (1994). Nutritional and medicinal values of mushrooms. In: Advances in Horticulture. (Chadha KL, Sharma SR eds.), Malhotra publishing house, New Delhi. pp. 537-551.

13. Buller AHR (1915). The fungus lore of the Greeks and Romans. Trans. Br. Mycol. Soc. 5: 21-26.

14. Rolfe RT, Rolfe FW (1925). The Romance of the fungus world. Chapman and Hall Ltd. London. pp. 309.

15. Singer R (1961). Mushrooms and Truffles, Leonard Hill Books Ltd. p. 272.

16. Lintzel W (1941). The nutritional value of edible mushroom proteins. Biochem. Acta. 308: 413-419.

17. Bano Z (1976). Nutritive value of Indian mushrooms and medicinal practices. Eco. Bot. 31: 367-371.

18. Crisan EV, Sands A (1978). Nutritional value. In: ST Chang and WA Hayes (Eds). The Biology and Cultivation of Edible
Mushrooms. London, Academic Press Inc. pp. 137-165.

19. Gruen VEC, Wong HX (1982). Immunodulatory and Antitumour activities of a polysaccharide-peptide complex from a mycelial culture of Trichoderma sp. Sciences. 57: 269-281.

20. Chang ST (1990). Future trends in cultivation of alternative mushrooms. Mush. J. 215: 422423.

21. Florezak J, Karmnska A, Wedzisz A (2004). Comparision of the chemical contents of the selected wild growing mushrooms. Bromatol. Chem. Toksykol. 37: 365-371.

22. Tseng YH, Mau JL (1999). Contents of sugars free amino acids and free 5- nucleotides in mushroom, Agaricus bisporus, during the post harvest storage. J. Sci. Food Agric. 79: 15191523.

23. Mc Connel JE, Esselen WB (1947). Carbohydrate in cultivated mushrooms. Food Res. 12: 118-121.

24. Crisan EW, Sands (1978a). A Nutritional value. In: Chang ST and Hayes WA (eds.). The biology and cultivation of edible mushrooms. Academic press, New York. pp. 172-189.

25. Yoshioka Y, Ikekawa T, Nida M, Fukuoka F (1975). Studies on antitumor activity of some fractions from basidiomycetes I. An antitumor acidic polysaccharide fraction of Pleurotus ostreatus (Fr.) Quel. Chem. Pharm. Bull. 20: 1175-1180.

26. Aletor VA (1995). Compositional studies on edible tropical species of mushrooms. Food Chem. 54: 265-268.

27. Hadded NA, Hayes WA (1978). Nutritional factors and the composition of the Agaricus bisporus mycelium. Mushroom Science. 10: 715-722.

28. Samajipati N (1978). Nutritive value of Indian edible mushrooms. Mushroom Sci. 10: 695703.

29. Chang ST (1980). Mushroom as human food. Bio Science. 30: 339-401.

30. Verma RN, Singh GB, Bilgrami KS (1987). Fleshy fungal flora of N. E. H. India- I. Manipur and Meghalaya. Indian Mush. Sci. 2: 414- 421.

31. Rai RD, Saxena S (1989a). Biochemical changes during the post harvest storage of button mushroom (Agaricus bisporus). Curr. Sci. 58: 508-10. 
J. Dhaka National Med. Coll. Hos. 2012; 18 (01): 58-62

32. Kallman S (1991). Nutritive value of Swedish wild plants. Svensk Bot. Tidskr. 85: 397-406.

33. Hayes WA, Haddad N (1976). The food value of the cultivated mushrooms and its importance in industry. Mushroom J. 40: 104110.

34. Hugaes DH (1962). Preliminary Characterization of the lipid constituents of the cultivated mushroom Agaricus campestris. Mush. Sci. 5: 540- 546.

35. Maggioni A, Passera C, Renosto F, Benetti E (1968). Composition of cultivated mushrooms (Agaricus bisporous) during the growing cycle as affected by the nitrogen source in compositing. J. Agr. Chem. 16: 517-519.

36. Yilmaz NM, Solamaz I, El mastas M (2006). Fatty acid composition in some wild edible mushrooms growing in the Middle Black region of Turkey. Food Chem. 99: 168-174.

37. Pedneault KP, Gosselia A, Tweddell RJ (2006). Fatty acid composition of lipids from mushrooms belonging to the family Boletaceae. Mycolog. Res. 110: 1179-1183.

38. Mattila PK, Konko M, Eurola J, Pihlava J, Astola L, Vahteristo V, Hietaniemi J, Kumpulainen N, Valtonen V, Piironen V (2000). Contents of vitamins, mineral elements and some phenolic compounds in the cultivated mushrooms. J. Agric. Food Chem. 49: 2343-2348.

39. Esselen WB, Fellers CR (1946). Mushrooms for food and flavor. Bull. Mass. Agric. Exp. Sta. 434.

40. Litchfield JH (1964). Nutrient content of morel mushroom mycelium: B vitamin composition. J. Food Sci. 29: 690-691.

41. Manning K (1985). Food value and chemical composition. Flegg PB Spencer DM, Wood DA (Eds). The biology and technology of the cultivated Mushroom. John Willey and sons, New York. pp. 221-230.

42. Sapers GM, Miller RL, Choi SW, Cooke PH (1999). Structure and composition of mushrooms as affected by hydrogen peroxide wash. J. Food Sci. 64: 889-892.

43. Anderson EE, Fellers CR (1942). The food value of mushrooms (A Campestris). Proc. Am. Soc. Hort. Sci. 41: 301.

44. Bano Z, Bhagya S,Srinivasan KS (1981). Essential amino acid composition and proximate analysis of Mushroom, Pleurotus florida. Mushrooms. News Lett. Trop. 1: 6-10.

45. Kalac P, Svoboda L (2000). A review of trace element concentrations inedible mushrooms. Food Chem. 69: 273-281.
46. Svoboda L, Zimmermannova K, Kallac $\mathrm{P}$ (2001). Concentrations of Mercury, Cadmium, Lead, and Copper in the fruiting bodies of the edible mushrooms in an emission area of a copper smelter and a mercury smelter. Sci. Total Environ. 246: 61-67.

47. Issilogglu M, Yilmaz F, Merdivan M (2001). Concentrations of trace elements in wild edible mushrooms. Food Chem. 73: 163-175.

48. Demirbas A (2001). Concentrations of 21 metals in 18 species of mushrooms growing in the east Black Sea region. Food Chem. 75:453-457.

49. Rudawska M, Leski T (2005) Macro and micro elemental contents in fruiting bodies of wild mushrooms from the Netecka forest in west - central Poland. Food Chem. 92: 499502

50. Sanme RB, Dell, Lumyoung P, Izumori K, Lumyoung S (2003). Nutritive value of popular wild edible mushrooms from Northern Thailand. Food Chem. 82: 527-532.

51. Manzi PS, Marconi Aguzzi A, Pizzoferrato L (2004). Commercial mushroom nutritional quality and effect of cooking. Food Chem. 84: 201-2006. 